\title{
Improving women's energy access, rights and equitable sustainable development: a Ghanaian perspective
}

\author{
De-Graft Owusu-Manu \\ Construction Technology and Management, \\ Kwame Nkrumah University of Science and Technology, Kumasi, Ghana
}

David Mensah Sackey

Department of Electrical/Electronic Engineering, Ho Technical University, Ho, Ghana

Dickson Osei-Asibey

Construction Technology and Management, Kwame Nkrumah University of Science and Technology, Kumasi, Ghana

Rachelle Kyerewah Agyapong

Department of Mechanical Engineering,

Kwame Nkrumah University of Science and Technology, Kumasi, Ghana, and

David John Edwards

Birmingham City University, Birmingham, UK

\begin{abstract}
Purpose - The purpose of the study is to investigate the challenges in improving women's energy access, rights and equitable sustainable development from a Ghanaian perspective.

Design/methodology/approach - The research utilizes a mixed method. A qualitative in-depth exploratory design was chosen to understand how gender is mainstreamed within Ghana's energy sector. This included semi-structured interviews with key managers, experience policy experts and focus groups. The semistructured interviews were analyzed using thematic content analysis (TCA).

Findings - The study reveals that the National Energy Policy of 2010, as the main energy policy regulating the energy sector in Ghana, does make provision for gender equality, safety especially women, in line with Ghana's sustainable development goals. The energy policy aims to empower women and create gender parity in the sector. Nevertheless, the study also found major challenges to gender mainstreaming in the energy sector, including poor analysis in formulating energy policies, inadequate financial resources, and poor monitoring and evaluation.

Originality/value - The paper exposes gender equity challenges associated with the energy sector in Ghana. It also offers a new policy angle which connects gender mainstreaming to sustainable development. The research describes how women are included in developing energy policies and in addressing gender challenges in the energy sector.
\end{abstract}

Keywords Gender mainstreaming, Environmental, Marginalized, SDGs, Sociocultural, Gender inequality, Climate change, Energy policy, Gender-inclusive

Paper type Research paper

C De-Graft Owusu-Manu, David Mensah Sackey, Dickson Osei-Asibey, Rachelle Kyerewah Agyapong and David John Edwards. Published in Ecofeminism and Climate Change. Published by Emerald Publishing Limited. This article is published under the Creative Commons Attribution (CC BY 4.0) licence. Anyone may reproduce, distribute, translate and create derivative works of this article (for both commercial and non-commercial purposes), subject to full attribution to the original publication and authors. The full terms of this licence may be seen at http://creativecommons.org/licences/by/4.0/ legalcode

Improving

women's

sustainable

development

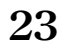

Received 24 May 2021

Revised 10 August 2021 Accepted 5 September 2021 
EFCC

3,1

\section{Introduction}

Energy is essential to preserving the quality of life and promoting economic development (Ding et al., 2014; Crentsil et al., 2019). Thus, achieving universal access to sustainable forms of energy in order to enhance the livelihoods of people around the world remains an important objective (REN21, 2019). Moreover, without energy services, disadvantaged people will be excluded from those basic amenities and risk being relegated to poverty (Fathallah and Pyakurel, 2020; Patnaik and Jha, 2020). Reversing this trend and improving access to sustainable energy is crucial, but requires political commitment and the will to set goals for energy poverty alleviation (Patnaik and Jha, 2020). Energy improves the well-being of women and men by making the production of goods possible, as well as through the provision of services, such as water, health, education and communications (Emmons Allison et al., 2019; OECD, 2019).

According to Ganle et al. (2015), women continue to shoulder the major responsibilities of household roles even though they are also actively engaged in the paid workforce in Ghana. Gender-responsive energy sector frameworks include considerations of the differentiated sociocultural experiences, as well as the needs and priorities, of women and men in order to overcome gender biases and integrate actions to promote gender equality and women's empowerment (Emmons Allison et al., 2019; Patnaik and Jha, 2020).

In as much as advocacies and reforms have boosted gender mainstreaming in most developing countries, growth in many of the Sub-Saharan African(SSA) countries, however, has resulted in little development and has brought only slight benefits to women (Klege et al., 2021). This research attempts to address how policies and programs within the energy sector can aid in attaining Sustainable Development Goals (SDGs) and proposes some recommendations toward gender mainstreaming in the Ghanaian energy sector.

The challenges associated with unsustainable patterns of development create gender inequality and women and children are most affected economically, socially and environmentally (Langer et al., 2015; Klege et al., 2021). At the same time, the importance of gender equality, the empowerment of women in the mainstream energy sector and the realization of the rights of women in achieving the SDGs have come to the forefront in recent studies (Klein and Whalley, 2015; Langer et al., 2015). Connecting the SDGs and gender equality is crucial. According to Langer et al. (2015), it helps in addressing the disproportionate impact of social, environmental and economic challenges undermining human rights that women face across the world (Lambrecht, 2016; Klege et al., 2021).

Asibey et al. (2021) studied gender differences and productive use of energy fuel in Ghana's rural non-farm economy. The paper uncovered that energy use varied across genders and enterprises. Similarly, energy access policies in Ghana fail to encourage gender inclusivity in identifying the energy needs of men and women for productive purposes. Asibey et al. (2021) conclude that policy interventions should identify gendered energy needs to address energy poverty between men and women. According to a research by Martey et al. (2021) on household energy choice for cooking among the time and consumption poor in Ghana using nationally representative household-level data. This was examined by employing different time poverty cut-offs and the bi-probit model. The paper proposed that key government institutions such as the Ministry of Energy and Petroleum should strongly promote Sustainable Energy for All(SE4ALL) initiative.

Baker et al. (2021) explored the marginalized in energy justice, amplifying community leader perspectives of energy transitions in Ghana using the value-focused thinking framework to inform stakeholder engagement. Light was illuminated on the gendered access to productive resources-evidence from smallholder farmers in Awutu Senya West District of Ghana by Ankrah et al. (2020). The study adopted a mixed-method including survey instrument, focus group discussions and key informant interviews. The research suggested that women of little educational background and class in patrilineal societies must be 
prioritized. In doing this, an intersectional gendered perspective taking into cognizance men and women differential access to productive resources to bridge existing gender gaps in context must be of paramount interest.

According to a research by Kansake et al. (2021) on creating a gender-inclusive mining industry: uncovering the challenges of female mining stakeholders. Kansake et al. (2021) found out that the key hindrances to a gender-inclusive mining sector include discrimination, harassment, gender ideologies and lack of support. Clearly, energy and gender research is being advanced but none of these studies have focused on poverty and energy as an issue and this limits the formulation of holistic evidence-based policies in addressing the problem. To address this deficit, this study, therefore, investigates the consequences of the disproportionate energy poverty endured by women in Ghana. In doing so, this paper was examined under the following objectives to (1) examine the effects of energy policies on gender mainstreaming in Ghana; (2) investigate the challenges in the energy sector militating against gender issues in achieving the SDGs in Ghana and (3) explore how energy policies are helping make energy affordable to households in the low-income bracket to achieve the SDGs.

The rest of the paper is structured as follows. Section 2 provides a literature review on gender mainstreaming in Ghana and related issues. Section 3 describes the methodology and data sources. Section 4 outlines the data analysis, with a discussion. Section 5 presents the outcomes, contributions and implications. Finally, conclusion and remarks are offered in Section 6.

\section{Gender mainstreaming}

\subsection{The gender gap concept}

According to DiPrete and Jennings (2012), gender gaps are caused by social rather than biological differences between women and men. Gender gaps are manifested in education, income, job opportunities, literacy, ownership of land, access to resources, access to credit, health, nutrition and participation in political activities and processes (Lambrecht, 2016; Crentsil et al., 2019). Despite the larger share of females in informal employment, gender inequalities in this sector are predominant (Ogando et al., 2017).

Gender gaps represent a severe constraining of women's economic advancement, especially in rural poor communities (Rosenthal et al., 2018; Shaaban et al., 2018; Crentsil et al., 2019; Koomson and Danquah, 2021). Indeed, the gender gap between women and men in certain positions continues to widen (Koomson and Danquah, 2021), with women restricted from the leadership selection process (Scholten and Witmer, 2017).

According to Khoza et al. (2019), women are not fully taking advantage of opportunities presented to them. Men, on the other hand, remain primary decision-makers, while women continue as the primary implementers of men's decisions. When it comes to less-developed sectors, women are not only deprived of recognition of their work but also suffer from different forms of harassment and violence (Lambrecht, 2016). At another level, they do not find opportunities to occupy higher positions within their working groups, or when they do, they are not respected by their male counterparts (Ogando et al., 2017).

Indeed, there are significant geographical and gender inequalities apparent in asset ownership and access to social services. According to the Ghana Statistical Service (2007), cited by Senadza (2012), education and health are particularly poor. Women face obvious and inherent discrimination in access to productive assets like land, credit, technology and livestock. They receive lower wages than their male counterparts in the labor market and work without remuneration as unpaid workers on family farms (Lambrecht, 2016; Tayal, 2019).

Nonetheless, women are gradually entering leadership positions in public service companies, though they continue to lack representation in the private sector. Gender equality has become lip service, occasionally useful to the organization but associated with uneasiness in management
Improving women's sustainable development

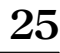


EFCC 3,1

structures and among men. Regardless of being successful at policy levels where legislations and programs ostensibly to reduce inequality have been introduced, women still remain broadly under-represented (Scholten and Witmer, 2017; Rosenthal et al., 2018).

\subsection{Gender mainstreaming in Ghana}

The awareness of gender similarity and variances have received considerable research interest (Ahmed and Gasparatos, 2020; Koomson and Danquah, 2021; Lambrecht, 2016). According to Scholten and Witmer (2017), gender mainstreaming is the practice of incorporating gender equality in all workgroups and organizational procedures, as opposed to considering it as a separate set of processes. Ahmed et al. (2016) argue that gender heterogeneity originates with different interests and authorities that need to be examined. Observing in wider gender lens, Ahmed et al. (2016) perceive gender as a crucial variable that is needed to form resource access control, class, race and culture.

Gender mainstreaming emerged as a concept in Mexico City, in 1975, during the World Conference on Women in the early 1990s (Klugman, 2009). Gender mainstreaming has been identified as a policy approach aimed at guiding governments across the world towards legally mandating women empowerment and gender equality (Sen and Mukherjee, 2014). Four major world conferences on women were organized by the United Nations. These took place in Mexico City in 1975, Copenhagen in 1980, Nairobi in 1985 and Beijing in 1995. The Fourth Conference on Women in Beijing manifests a major landmark for the global agenda for gender equality. The Beijing Declaration during the conference, that was unanimously adopted by 189 countries, set the agenda for women's empowerment and considered the key global policy document on gender equality (The Beijing Declaration on Research Data, 2020).

In Ghana, the government requires that ministries, departments and agencies (MMDAs) work to mainstream gender into their policies and programs. Ghana's goals towards achieving gender mainstreaming are guided by the 1992 Constitution. The targets in National Development Framework (NDF), and the commitment to International Frameworks on human rights and development with emphasis on rights of women, men and children. In addition, the government also issued a White Paper on Affirmative Action in 1998 as a demonstration of its commitment (Appiah, 2015).

Regarding gender and climate, the Ghana Environmental Protection Agency (EPA) under the Ministry of Environment Science and Innovation (MESTI) also highlighted key gender adaptation issues in the National Adaptation Plan (NAP) (Republic of Ghana, 2020). Furthermore, the National Gender Policy promulgated in 2015 as the framework for implementing gender mainstreaming in Ghana. The policy strategies for empowering women and gender equality emphasize gender mainstreaming as a core business in promoting equity, socio-economic development and human rights dispensation. They are considered strategies by government departments and non-governmental organizations (NGOs) towards explicitly targeting women in order to increase their participation in communities as complementary associates and address developmental challenges (Khoza et al., 2019).

\subsection{Gender and sustainable development}

Gender equality is when both men and women enjoy the same opportunities irrespective of where they find themselves (Ankrah et al., 2020; Asibey et al., 2021). The objective of gender equality and empowerment has been targeted in SDG5, being critical to achieving the United Nations sustainability goals (Tayal, 2019; Baker et al., 2021). The United Nations states:

We recognize that gender equality and women's empowerment are vital to sustainable development and our common future. We confirm our obligations to ensure women's equal rights, access, and opportunities for participation and leadership in the economy, society, and political decision-making. We underscore that woman have a vital role to play in achieving sustainable development. 
We recognize the leadership role of women, and we resolve to promote gender equality and women's empowerment and to ensure their full and effective participation in sustainable development policies, programs and decision-making at all levels (UN, 2012).

In this regard, poverty reduction, gender equity and sustainability are important objectives for development (Ankrah et al., 2020; Baker et al., 2021). Thus, a discussion about women and energy must be linked with theoretical considerations around two key streams of theory and practice adopted for this research. The first being women in development (WID) and the second being gender and development (GAD). WID stipulates the position that women have been left out of development and need to be integrated if they are to enjoy equal benefits. While $\mathrm{GAD}$ positions that women have always contributed to the development, but from an unequal position and without recognition (Ahmed, 2016; Asibey et al., 2021; Baker et al., 2021) The $\mathrm{GAD}$ perspective called for a complete transformation of the development industry in order to place gender at the center of the development agenda. This was highlighted in the REN21 (2019) report of which $32 \%$ of the renewable energy workforce is made up of women, yet they account for just $22 \%$ of the oil and gas workforce. A similar viewpoint was shared by Kansake et al. (2021) that males dominated many engineering fields such as energy.

\subsection{Energy and sustainable development}

Many African countries consider sustainable development as the fulcrum of their development agenda (Ahmed and Gasparatos, 2020; Koomson and Danquah, 2021; Martey et al., 2021). Ahmed et al. (2016) and Lambrecht (2016) observe that even though men and women farmers both experience climate change, it is predominantly men that engage in practices and decision making to mitigate its impact. Human activities have increased in recent years and are leading to unprecedented catastrophic environmental events, such as hurricanes, flooding, earthquakes and famine (Wang and Zhou, 2019; Lovelock and Reef, 2020). Climate change has given rise to drought, compounded by human-induced activities, increasing desertification, the degradation of natural resources, while also magnifying conflict drivers.

In the view of Pareek et al. (2020), these environmental problems destabilize people's livelihoods and health, with the cost and consequences disproportionately affecting women and children. These affect different socio-economic groups in diverse ways, making considerations of gender crucial to understanding the impact of climate change (Pariyar and Kulathuramaiyer, 2019; Phan et al., 2019). The Brundtland Report (Our Common Future) (World Commission on Environment and Development, 2017) defined sustainable development as, a development that meets the needs of the present, without compromising the ability of future generations to meet their own needs. This notion presents a notable shift from a prior understanding of development as equivalent to economic growth.

In sum, the national sustainable development objectives will be achieved more readily when the needs of women, as well as men, are included in national policies. Along the same lines, sustainable development can only be achieved through long-term investment in economic, human and environmental capital (World Commission on Environment and Development, 2017). Drawing on these observations, gender and sustainability should therefore be implemented as shared and complementary processes. To do so, however, it is necessary to establish a common conceptual framework to ensure gender equality through the promotion of energy justice at the policy level (Bulkeley et al., 2014; Whyte, 2020; Gonzalez, 2021). Such methodology should draw upon locally relevant best practices.

\subsection{The link between gender mainstreaming, energy and sustainable development}

Mubaya et al. (2017) theorize that the considerations for sustainable development and climate adaptation responses do not necessarily have to consider women as a special social group in isolation but, rather consider the implications for both men and women.

\section{Improving women's sustainable development}

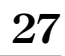


EFCC 3,1

Women play a major role in Africa's food production sector, comprising two-thirds of the agricultural labor force (Lambrecht, 2016). In their role as food producers, women face discrimination affecting not only their well-being but also imposing high costs on the economy through poverty and deprivation (Adubra et al., 2019; Brandão et al., 2020; McKay et al., 2020) Available statistics from many authors (Gartaula et al., 2017; Diiro et al., 2018; Mahajan, 2019) indicate that should women have access to same productive resources as men, their farms could increase yields from between 20 and 30\%. This represents a potential agricultural output increase in developing countries of between 2.5 and $4 \%$, in turn, reducing world hunger by $12-17 \%$. Moreover, gender equality stimulates economic efficiency and is vital to achieving other development outcomes. Gender fairness is crucial to promoting shared growth and accelerating the achievements of the third SDGs (Tavenner et al., 2019). As such, gender mainstreaming is indispensable to advancing gender impartiality in organizational activities (Tavenner et al., 2019).

\subsection{Theoretical framework}

For this research, the two major streams of theories have been adopted. The first is "Women In Development" (WID) and "Gender and Development" (GAD). Tourigny et al. (2017) holds the position that developmental issues do not include women, but should, in order to benefit them. The GAD theory stipulates that women have always participated in the development, but from an unequal position and without being acknowledged. This theory was suitable for this research and is adopted because, according to March et al. (1999), cited by (Mubaya et al., 2017), development gender mainstreaming - as distinct from women and development. A study by Smith (2013) emphasizes same that gender occurs through five sets of relations: power relations, production relations, cathexis or emotional relations, and symbolic relations.

Interestingly, these theories elucidate vital inquiries that help in understanding the study problem and what potential solutions could be. Nevertheless, it was useful for this study in assessing how gender is practiced in the Ghanaian context and how different sets of relationships can be mobilized in situations such as women's energy access. Tourigny et al. (2017) posit gender mainstreaming as a model to advance a more gender-equal recruitment process, focusing on the structural dimensions of gender in society. According to Tourigny et al. (2017), GAD supporters argue that the fundamental constraints for women's advancement are the social structure and processes which create and maintain male superiority and female subordination.

2.6.1 Conceptual framework. For this research (Van Meter and Van Horn, 1975), policy implementation framework was adopted. The model has been described as the starting point for the study of the implementation policy process. According to Hill and Hupe (2003) the model departs from earlier perspectives like that of Pressman and Wildavsky in aiming to direct implementation, as opposed to merely presenting a prescription. The model begins by proposing to segment policies in terms of what implementation challenges can be identified. Hill and Hupe (2003) hypothesized that implementation will be most be effective where marginal modifications are required and intention consensus is high. According to Rothstein (1998), cited by Simpson and Buabeng (2013), a policy must demonstrate three core factors of sound design, organization of the implementation process and political legitimacy. To show how specific factors may impede or promote implementation, they propose six core variables. They include policy standards and objectives; policy resources, inter-organizational communication and enforcement activities, characteristics of implementing agencies, economic, political and social conditions, and the disposition of implementers. These core variables are deemed responsible for shaping the relationship between public policy and implementation, along with its subsequent successes or failures.

The model by Van Meter and Van Horn provides a useful explanation of the correlation between variables of a public policy to its output while offering a guide to implementation. 
The model also outlines a wide range of variables, thereby making it applicable to a wide range of situations (Hill, Michael Hupe, 2003). However, Simpson and Buabeng (2013) point out that the probability of effective implementation will depend on the type of policy being considered and that the explicit factors contributing to the realization of program objectives will vary from one policy type to another.

Referencing the research objective, the system can be delimited by energy policies, sustainable development, economic, socio-cultural issues and political issues, while gender can be set as the boundary for this system. Gender and energy mainstreaming efforts can be seen as a disruptor that can spark a chain of reaction regarding how society is organized with regard to social norms, societal roles and functions, economic issues, political roles and religious issues. From a simplistic interactive perspective, gender mainstreaming is expected to lead to women's empowerment. However, from the systems theory perspective, many factors will first have to interact to create this change. For instance, for gender and energy mainstreaming to lead to the achievement of the SDGs, many actors and phenomena must interact in a feedback loop that may be negative or positive. These may include various policies, programs, laws, regulations, along with the stakeholders who may support or oppose these.

Gender and energy mainstreaming is an open system that relies on multi-layered systems. In order to achieve the SDGs, the interactions between development organizations, government, civil society, the media and research institutions within the society, must all be understood and proactively directed. A review of the implementing organizations, along with an assessment of available resources and current levels of coordination and collaborations, reveals Ghana's potential for delivering the SDGs, is conditional on it adequately addressing its gender issues. The literature, however, also pointed to complex challenges that threaten to impede policy implementation, which in turn would influence energy policy implementation and hence the achievement of the SDGs.

\section{Material and method}

The research utilized a mixed method backed with an in-depth qualitative approach. This approach was used because it provides a comprehensive understanding of the context within which the social phenomenon of the role of gender in the energy sector is helping to achieve the SDGs (Agbodji et al., 2015). In addition, this approach also provides an understanding of the issues from the perspective of the people experiencing and implementing the policies. A purposive sampling technique was used in this study. Thus, interviews were conducted with preselected people with the requisite experience and knowledge in this area (Tongco, 2007). In evaluating the profile of respondents, the length of time working in the field and relevance of involvement was considered in assessing expertise and therefore interview suitability (Hallowell and Gambatese, 2009). The data for the research were collected from primary sources through one-on-one semi-structured interviews. This gave respondents the freedom to express themselves and also gave the researcher the autonomy to ask follow-up questions. During the interviews, field notes were taken. Secondary data were utilized via a literature review, including analysis of project reports, published books and papers.

In total, 25 respondents, based on their roles and expertise, were selected for interview from the following institutions, 5 from the Ministry of Energy, 5 from the Gender and Social Protection Ministry, 3 from the Energy Commission, 4 from the Millennium Development Authority, 3 from the University of Mines and 5 from the Energy for Development Program. Sorting of data into various groupings was done, after which these were labeled according to topics to facilitate processing. The categorization was later used to generate themes that coincided with the objectives of the research. The recorded interviews and notes were transcribed, documented and sorted. The study used thematic content analysis (TCA) to analyze the harvested research data.

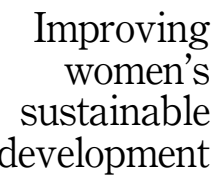

29 
EFCC 3,1

TCA is a descriptive presentation of qualitative data (Soratto et al., 2020). According to Krippendorff (2011), TCA is one of the most powerful research techniques in social science, able to analyze data within a specific context such as group or culture (Owusu-Manu et al., 2020). The key characteristic is the systematic coding, examination of meaning and provision of a description of the social reality through the creation of themes. First, the researcher reproduces copies of the interview transcript. Second, themes are identified, focusing on notable elements in the texts (Vaismoradi et al., 2016). Third, similar units were extracted and arranged together (Sandelowski and Leeman, 2012). The entire interview transcript is reviewed for suitability of identified thematic groupings, revised and if necessary, regrouped (Krippendorff, 2011). Finally, to facilitate the production of high-quality findings, this procedure is repeated until all the extracted categories reflect the interview transcripts as a whole (Vaismoradi et al., 2016). TCA was adopted by Abubakari et al. (2013) and Simpson and Buabeng (2013) to investigate the implementation of public-private partnerships in Africa and performance contracts of public enterprises, respectively. Findings were compared with the literature to ascertain which views corroborated and which contradicted published knowledge, as an aid to formulating conclusions.

\section{Results}

The study used TCA to analyze the research data. According to Hsieh and Shannon (2005), this analytical approach aids in interpreting the meaning of what respondents say. The text produced from the interviews must have meaning to the researcher, hence, the reading of the text, the use of the text within its social context, and the analysis of the text is an important aspect in content analysis (Krippendorff, 2011).

The next stage consolidated the detailed narration of the raw field data into a coherent data report. The study conducted an analytical discussion of the research findings with the view to conveying a detailed analysis of the data. This phase of the study involved in-depth discussions of the findings using the themes identified. There were also instances where appropriate quotations from research participants were cited as demanded by the context. The final phase of the analysis focused on the presentation of the analytical interpretation of the research findings, along with emergent lessons and conclusions.

As captured in the National Energy Policy (NEP) of 2010 (Ministry of Energy, 2010), the NEP seeks to address clean and affordable energy as well as providing equal opportunities for women in the energy sector. The policy has made provision for gender equality, safety and security of all Ghanaians, especially women, which is in line with the requirements of its SDGs. This is captured in clauses 1.5.5 and 1.5.6, which promote gender mainstreaming in the energy sector. The NEP affirm the findings from (Musango et al., 2020; Feenstra and Ozerol, 2021) energy matters are of major interest to all, however, women are one of the most vital players in the energy sector, in relation to their contact, use and management of renewable energy sources.

Applying the theoretical framework, the findings revealed that these energy policies on gender mainstreaming are helping empower women while creating gender parity in the sector. For instance, one aspect of the energy policy focuses on enhancing the capability of women to influence decision-making in the energy sector while also educating them on their rights. Commenting on this, a respondent asserted that:

These policies are formulated to improve the lives of women and advance the agenda to reduce the disparity between men and women in the energy sector of Ghana and also empower them to participate fully in the energy sector.

Research respondents were also asked if the current energy policy can succeed in advancing gender equality to achieve the SDGs. Their responses were in the affirmative but some also 
mentioned that it will require more effort since the policy is still in its draft stage. Commenting on this, an official from the ministry of energy said that:

The policy would no doubt go a long way to encourage female participation in the energy sector through various programs and also reduce the health risk of women in the rural areas.

This infers that the necessary measures are being put in place to ensure the effective implementation of the policy. As to what gender mainstreaming is, the various responses from the interviewees point out that, there was a clear understanding of mainstreaming as a strategy that entails bringing all the gender issues into the mainstream. This is to promote the socio-economic welfare of both men and women. A respondent at the Ministry of Women and Gender lamented that:

Currently, it looks like the men are marginalized in the whole process. This is due to the notion that women in Ghana have been marginalized for far too long and this is the opportunity to bridge the gap.

The research findings also show that most of the interviewees equated gender issues to women issues. There was an emphasis on the involvement and participation of women in energy policies and programs, and the general observation was that the various stakeholders in the energy sector are formulating and implementing various policies and programs which are in line with gender mainstreaming in the energy sector. One such program was a scholarship package for women to study energy-related courses. An interviewee commenting on this issue asserted that:

These days women's issues in the energy sector are very important. The various stakeholders in the energy sector are giving opportunities to women. It is very important for us as a nation to bridge this gap to achieve the SDGs.

The definition and roles of gender have helped in bridging the gap between men and women; however, there is a risk that it strengthens instead of challenging the gender stereotypes in Ghana. Moreover, it is equally important to consider the implications of gender-related policies on all stakeholders when introducing them. This will call for ways and strategies to convince all stakeholders to buy into the policy to address possible resistance that might negatively affect the policy. Even though gender mainstreaming looks at both men and women, there is an automatic association of gender with women the study shows Ahmed et al. (2016), Mubaya et al. (2017), Scholten and Witmer (2017) explain that gender mainstreaming is an inclusive strategy that covers a broad facet of development, hence the need to include both men and women.

From these findings, it can be seen that gender mainstreaming is primarily focused on women, because of their history of marginalization. Thus, women are the focus of gender mainstreaming in Ghana rather than women being a part of the process.

\subsection{Energy policies making household energy affordable}

This study identified the various energy policies that are being implemented to make energy affordable to households in Ghana. The interviews with the research respondents revealed the following.

4.1.1 Tax and tariff reduction on energy. The government of Ghana has identified taxes as a major hurdle to making energy affordable to low-income households. In respect of this challenge, the study discovered that the government of Ghana reduced tariffs on electricity by $17.5 \%$ for households in March 2018, and also amended the Special Petroleum Tax Amended Bill to reduce the tax from $15 \%$ to $13 \%$. The amendment was a response to the rising cost of fuel, which was making it difficult for households in the low-income bracket to access energy. This was also negatively affecting the chances of Ghana meeting the SGDs.
Improving women's sustainable development 
EFCC 3,1

The achievement of SDGs requires that petroleum and electric tariffs and taxes be relatively low, as this supports poor household's access to quality and clean energy. Moreover, it is typically women who suffer the brunt of high tariffs and taxes, since they have to substitute fuel sources through the collection of firewood (Ahmed, 2016). Therefore, when tariffs and taxes on energy are low, poor households' benefit, which is critical for a lower-middle-income country like Ghana.

4.1.2 Education. The Ministry of Energy is partnering with the Millennium Development Authority to recruit female engineering students to undertake a periodic internship with energy agencies in the country. Outreach programs are being embarked on in senior high schools to encourage and educate female students in the energy sector, and to study science, technology, engineering and mathematics (STEM) (Senadza, 2012). It was pointed out by one of the respondents that this was aimed at ensuring the equal participation and promoting gender equity in the energy sector. An official of the ministry of energy commenting on this said:

We look at the number of women representations at all levels in the energy sector and most importantly whether they are involved in the planning and implementation of energy policies and programs. That is a very significant measure of gender mainstreaming.

Another official also asserted that:

Outreach programs are being held in the second cycle school to educate them on the opportunities in the engineering fields which will also increase the intake of female students into the tertiary level. In addition, we must identify girls who are interested in science-related courses so we can help them choose educational paths that can enable them to be recruited into the energy sector.

About increasing the interest of both men and women, Kwame Ameade and Majeed (2015) noted that there are fewer discussions on how to motivate girls and women to have an interest in subjects where boys and men have dominated. This shows that there is an ongoing program aimed at enhancing the capacity of women to take up roles in the energy sector.

4.1.3 Local content policy framework on energy. The study found that not all the stakeholders in the sector agree on the objectives and strategies being used to achieve local content. Some of the respondents were of the opinion that, even though the policy aims at promoting women through affirmative action, it would be better to use absolute figures to determine progress instead of relying on percentages. That is, the focus should be on reserving some positions for women in absolute terms, such that they will not be pushed to the periphery in the decision-making process. Moreover, it was also revealed that there is limited stakeholder involvement in policy implementation, even though the policy aims to promote the interests of women in the sector.

The relationship between energy and gender will determine the type of policies and programs that will be formulated and implemented (Kusch-Brandt, 2019; Tayal, 2019) to address the gender gap in the energy sector in Ghana. This is because its sole focus is on women which must also include women's income, ethnic background and other equally significant factors. Interestingly, the findings show that the policies and programs that can improve gender mainstreaming in the energy sector may end up benefiting only men or women without necessarily benefiting both.

Some various policies and programs have been employed to address gender inequalities in the energy sector across the world (Tourigny et al., 2017). This is because access to 
dependable and quality energy is a prerequisite to reducing poverty and improving human lives. In developing these policies and programs, data are critical to enhancing the chances of these policies and programs succeeding. Women use energy differently from men and for different purposes, hence the need to look beyond the socially constructed definition of gender in developing energy policies to promote gender mainstreaming.
Improving women's sustainable development

\subsection{Gender challenges in achieving sustainable energy goals in the energy sector}

4.2.1 Lack of alternative gender goals for energy projects. The research discovered that the reliance on empowering women in gender analysis in energy policies is making it problematic for energy policymakers in Ghana (Opoku and Glazebrook, 2018). Energy policymakers find it difficult to implement projects and programs that could be useful in bridging the gender gap in the energy sector. Additionally, it was also discovered that different gender goals should inform different energy projects in the country. However, because of the official policy focus of empowerment, standard gender mainstreaming strategies and programs fail to question what the real gender goals are, and thus fail to provide indicators that can be used to review whether such projects have been effective in helping achieve gender goals (Adzawla et al., 2019).

4.2.2 Poor gender mainstreaming analysis in formulating energy policies. The study revealed that standard gender analytical tools are used to identify the differences between men and women. However, these analytical tools fail to identify the various social classes of women in local communities that ought to be consulted to formulate energy policies that can meet their needs; not only in terms of energy but a range of economic factors (Ahmed, 2016; Baker et al., 2021) confirm that there is a lack of intersectional approach to addressing gender mainstreaming issues, even though there are various women groups. For instance, women from the richer social classes may use gas for cooking while poorer women use firewood and charcoal. Therefore, gender mainstreaming issues are seen as including women and men from different economic and socio-cultural backgrounds (Tayal, 2019).

4.2.3 Inadequate financial resources. Within ministries and departments, it is a standard organizational practice that units are established to execute policies and programs. The same is true regarding energy policies and gender mainstreaming of the government institutions mandated to champion these policies. The study revealed that financial resources to implement energy policies and programs are limited. Disbursement of funds to ministries and departments is chronically delayed, and when disbursed are usually short of the required amount. This challenge undermines the effectiveness of public policies and programs, and energy policies are no exception. In addition, the study shows that financial constraints make it difficult for institutions to pursue gender mainstreaming because a lack of funds curtails the ability to organize workshops, seminars and stakeholder meetings.

4.2.4 Poor monitoring, evaluation and reporting. Interviews with the respondents at the ministry show that even though monitoring of energy and gender programs are crucial for their success, a lack of resources means they are unable to do so effectively. A staff of the ministry of energy lamented that:

Because of the lack of vehicles, it is difficult for us to monitor projects and this is a major cause of most project failures in the ministry.

The lack of official monitoring of gender and energy programs in Ghana means that irrespective of the number of policies and programs implemented, without proper monitoring of these programs it remains difficult to bridge the gender gap in the energy sector and also help achieve the SDGs.

4.2.5 Women's involvement in energy policy formulation and implementation. Identifying the diverse goals of gender in addressing energy gaps in Ghana raises the question of who among the stakeholders determines the goals guiding energy and gender policies. Research 
EFCC 3,1

respondents were asked to describe the level of participation of women in the formulation and implementation of energy and gender policies in Ghana. The study confirms the findings of (Clark Muntean and Ozkazanc-Pan, 2014) that there is little participation of women in the formulation and implementation of these policies, largely because the cohort of people mandated to formulate and implement these energy policies are dominated by men as confirmed by (Kansake et al., 2021).

Promoting women into leadership positions in the energy sector would link women to energy policy formulation for the benefit of women. This is one way of mainstreaming gender in the energy sector, with more women benefiting. However, the study revealed that the energy sector in Ghana is dominated by men even though there is no accurate data to report on this. All respondents confirmed this when asked. In Ghana, women are underrepresented on boards of various organizations in the energy sector as well as in managerial positions. Another reason is that the institutional culture of these organizations in the energy sector is male-oriented, making it difficult for women to reach higher positions in Ghana.

Even though some progress has been made in employing more women in the energy sector, the pace has been slow, leaving a wide gender gap in the workforce in the energy sector. This was confirmed in the report by (REN21, 2019) that $32 \%$ of the renewable energy workforce is made up of women, with $22 \%$ in the oil and gas sector. The entrenched norms and values of senior officials mandated to ensure gender parity in the energy sector are evident in their inability to deliver change. On the surface, they create a politically correct impression of being fully supportive of gender mainstreaming in the energy sector. However, at the implementation phase, commitment and support are elusive. According to a female respondent at the energy commission:

Most of these male directors and managers only pay lip service to the issue of gender mainstreaming in the energy sector. If more women are brought into the energy sector, they can champion the course of women better than men. Most of these men are happy with the status quo and are also happy to see men dominate in the sector. We will need more women in the energy sector if we can bridge the gender gap in the energy sector from a policy perspective.

This shows a powerful masculine resistance by individuals not committed to promoting and ensuring that more women are given opportunities in the energy sector. The lives of women can be improved if they are allowed to participate in the energy sector.

The findings reveal that gender mainstreaming issues in Ghana have been equated to gender equality and this is affecting energy policies that impact gender issues in the sector. Consequently, gender mainstreaming in energy policies and programs in Ghana lacks a coherent approach, focusing on women instead of both men and women. This creates gaps in these energy policies, with women seen as a homogenous group without socio-cultural identities other than their sex.

In formulating and implementing gender policies in the energy sector, stakeholders must appreciate the implications of the various external and internal factors. This was espoused by Baker et al. (2021) and Kansake et al. (2021); they emphasize that the key element in gender mainstreaming will be a shift from the quantitative participation of men and women to a more transformative approach that will positively transform the lives of people. Evidence from studies on women's participation in organizational decisions reveals that there are differences in access to education, networking behavior, and capital and that these factors are impeding the participation of women in various sectors of the economy in many developing countries (Lambrecht, 2016; Kansake et al., 2021)

In conclusion, it appears that gender mainstreaming in the energy sector is treated as a checkbox for politicians to tick, to publicize to the international community that the government is doing something to bridge the gap between men and women in the energy sector. However, without the required resources to implement energy policies, achieving 
gender mainstreaming in the energy sector and the subsequent achievement of the SDGs on gender parity and energy access will not be substantially realized.

\section{Discussion}

The NEP is helping to empower women and create gender parity in the Ghanaian energy sector. Even though gender mainstreaming includes both men and women, the study reveals that the needs of men are mostly neglected in gender mainstreaming policies and programs in the energy sector in Ghana. The study sought to identify the various energy policies that are being implemented to make energy affordable to households in Ghana. Tax and tariff reduction policies on energy are one of the main strategies. Other policies and programs identified include providing scholarships under the education in STEM program. These policies are helping to bridge the educational gender gap, by providing scholarships for girls in the education sector.

Also, the study discovered that the apparent focus on empowerment of women as the motivation for applying gender analysis in energy policies is making it problematic for energy policymakers in Ghana. Moreover, different gender goals should inform different energy projects in the country. Other challenges identified include poor gender mainstreaming analysis in formulating energy policies, inadequate financial resources, poor access to information, poor monitoring and insufficient evaluation and reporting.

Furthermore, the research found that there is little participation of women in the formulation and implementation of these policies because the cohort of people mandated to formulate and implement these energy policies is dominated by men. This results in women being underrepresented on the boards of various organizations in the energy sector, as well as in managerial positions. There is an entrenched masculine resistance to promoting more women into positions of power in the energy sector. Hence, until women are given positions of power to champion gender mainstreaming in the energy sector instead of this being entrusted to their current male counterparts, the agenda to promote more women into the energy sector will continue to encounter resistance.

There have been many empirical studies on gender mainstreaming in developing countries however, most of these studies have focused on issues such as the mainstream service sector, banking, education and sports, leaving a paucity of studies in the energy sector. This study contributes empirically to the body of knowledge on gender mainstreaming in the energy sector and its associated challenges. It is also envisaged that this study will guide other scholars in future research within a developing country context to expand the body of literature on gender mainstreaming. Light has been shed on some of the impeding policy barriers which is vital for national policy review and amendment.

\section{Conclusion}

This study investigates the challenges associated with energy policies in addressing gender issues in achieving the SDGs in Ghana. The inability of energy policymakers to consider the existing reality of gender disparities in the formulation and implementation of energy policies leads to gendered results. In order to avoid energy policies creating negative effects on gender equality, such policies need to be gender mainstreamed. The approach to gender mainstreaming requires the adoption of an appropriate comprehension of gender. That one goes beyond women and pays attention to gender systems as a unit. Energy policies in gender mainstreaming should lead to a deconstruction of existing gender and energy systems.

The research concludes that a major challenge to gender mainstreaming in the energy sector is poor gender mainstreaming in formulating energy policies, inadequate financial resources, insufficient access to information, and lack of evaluation and reporting. This study

\section{Improving women's sustainable development}

35 
EFCC 3,1

suggests that the government of Ghana must ensure that MDAs are well-resourced, both financially and with skilled personnel. This would augment monitoring processes which in turn would enhance the successful implementation of energy policies with gender equity in the sector. Identification of these needs is a prerequisite to developing gender-responsive policies. Third, is the need for more investment in energy infrastructure technologies to create adequate opportunities for women in the sector. Finally, government must ensure that women get equal participation in senior management and decision-making processes at all levels of the energy sector.

The research adopted a purely qualitative approach and future studies can either use a mixed-method approach or a quantitative approach in conducting similar studies. Moreover, the study was geographically contextualized to Ghana. In adopting a qualitative approach, this study conducted 25 interviews, and as such can only be selectively representative of the full range of perspectives that may be held by experts with insight into this area. Hence, future studies can expand this sample size to enhance the validity of the research findings. In the future, it will be necessary to unravel the impact of women energy access on the microhouse income. In particular, it will be important to measure its impact on the country's performance in poverty alleviation.

\section{References}

Abubakari, M., Buabeng, T. and Ahenkan, A. (2013), "Implementing public private partnerships in Africa:the case of urban water service delivery in Ghana", Journal of Public Administration and Governance, Vol. 3 No. 1, pp. 41-56, doi: 10.5296/jpag.v3i1.3252.

Adubra, L., Savy, M., Fortin, S., Kameli, Y., Kodjo, N.E., Fainke, K., Mahamadou, T., Le Port, A. and Martin-Prével, Y. (2019), "The minimum dietary diversity for women of reproductive age (MDDW) indicator is related to household food insecurity and farm production diversity: evidence from rural Mali”, Current Developments in Nutrition, Vol. 3 No. 3, p. 002, doi: 10.1093/cdn/nzz002.

Adzawla, W., Azumah, S.B., Anani, P.Y. and Donkoh, S.A. (2019), "Gender perspectives of climate change adaptation in two selected districts of Ghana", Heliyon, Vol. 5 No. 11, p. 2854, doi: 10. 1016/j.heliyon.2019.e02854.

Agbodji, A.E., Batana, Y.M. and Ouedraogo, D. (2015), "Gender inequality in multidimensional welfare deprivation in West Africa: the case of Burkina Faso and Togo", International Journal of Social Economics, Vol. 42 No. 11, pp. 980-1004, doi: 10.1108/IJSE-11-2013-0270.

Ahmed, A. and Gasparatos, A. (2020), "Multi-dimensional energy poverty patterns around industrial crop projects in Ghana: enhancing the energy poverty alleviation potential of rural development strategies”, Energy Policy, Elsevier, Vol. 137, p. 111123, doi: 10.1016/j.enpol.2019.111123.

Ahmed, A., Elaine, T.L., Adelina, M., Chris, G. and Jon, P. (2016), "Adaptation to climate change or non-climatic stressors in semi-arid regions? Evidence of gender differentiation in three agrarian districts of Ghana”, Environmental Development, Elsevier, Vol. 20, pp. 45-58, doi: 10.1016/j. envdev.2016.08.002.

Ahmed, M.E. (2016), “A gender justice approach to eliminating Sudan's Savannah belt's vulnerability to climate change", International Journal of Climate Change Strategies and Management, Vol. 8 No. 4, pp. 539-558, doi: 10.1108/IJCCSM-06-2015-0085.

Ankrah, D.A., Freeman, C.Y. and Afful, A. (2020), "Gendered access to productive resources evidence from small holder farmers in Awutu Senya West District of Ghana", Scientific African, Elsevier B.V., Vol. 10, p. 604, doi: 10.1016/j.sciaf.2020.e00604.

Appiah, E.M. (2015), "Affirmative action, gender equality, and increased participation for women, which way for Ghana?”, Statute Law Review, Vol. 36 No. 3, pp. 270-279, doi: 10.1093/slr/hmv016.

Asibey, M.O., Ocloo, K.A. and Amponsah, O. (2021), "Gender differences and productive use of energy fuel in Ghana's rural non-farm economy”, Energy, Vol. 215, p. 119068, doi: 10.1016/j.energy.2020. 119068 . 
Baker, E., Nock, D., Levin, T., Atarah, S.A., Afful-Dadzie, A., Dodoo-Arhin, D., Ndikumana, L., Shittu, E., Muchapondwa, E. and Sackey, C.V.H. (2021), "Who is marginalized in energy justice? Amplifying community leader perspectives of energy transitions in Ghana", Energy Research and Social Science, Vol. 73, p. 101933, doi: 10.1016/j.erss.2021.101933.

Brandão, E.A.F., Santos, T.da R. and Rist, S. (2020), "Connecting public policies for family farmers and women's empowerment: the case of the Brazilian semi-arid", Sustainability, Vol. 12 No. 15, p. 5961, doi: 10.3390/SU12155961.

Bulkeley, H., Edwards, G.A.S. and Fuller, S. (2014), "Contesting climate justice in the city: examining politics and practice in urban climate change experiments", Global Environmental Change, Vol. 25 No. 1, pp. 31-40, doi: 10.1016/j.gloenvcha.2014.01.009.

Clark Muntean, S. and Ozkazanc-Pan, B. (2014), "A gender integrative theory of entrepreneurship", Academy of Management Proceedings, Vol. 2014 No. 1, p. 15508, doi: 10.5465/ambpp.2014. 15508abstract.

Crentsil, A.O., Asuman, D. and Fenny, A.P. (2019), "Assessing the determinants and drivers of multidimensional energy poverty in Ghana”, Energy Policy, Vol. 133, p. 110884, doi: 10.1016/j. enpol.2019.110884.

Diiro, G.M., Seymour, G., Kassie, M., Muricho, G. and Muriithi, B.W. (2018), "Women's empowerment in agriculture and agricultural productivity: evidence from rural maize farmer households in western Kenya”, PLoS One, Vol. 13 No. 5, p. 197995, doi: 10.1371/journal.pone.0197995.

Ding, W., Wang, L., Chen, B., Xu, L. and Li, H. (2014), "Impacts of renewable energy on gender in rural communities of north-west China”, Renewable Energy, Vol. 69, pp. 180-189, doi: 10.1016/j.renene. 2014.03.027.

DiPrete, T.A. and Jennings, J.L. (2012), "Social and behavioral skills and the gender gap in early educational achievement", Social Science Research, Vol. 41 No. 1, pp. 1-15, doi: 10.1016/j. ssresearch.2011.09.001.

Emmons Allison, J., McCrory, K. and Oxnevad, I. (2019), "Closing the renewable energy gender gap in the United States and Canada: the role of women's professional networking", Energy Research and Social Science, Elsevier, Vol. 55, pp. 35-45, doi: 10.1016/j.erss.2019.03.011.

Fathallah, J. and Pyakurel, P. (2020), "Addressing gender in energy studies”, Energy Research and Social Science, Vol. 65, p. 101461, doi: 10.1016/j.erss.2020.101461.

Feenstra, M. and Özerol, G. (2021), "Energy justice as a search light for gender-energy nexus: towards a conceptual framework", Renewable and Sustainable Energy Reviews, Vol. 138, p. 110668, doi: 10.1016/j.rser.2020.110668.

Ganle, J.K., Afriyie, K. and Segbefia, A.Y. (2015), "Microcredit: empowerment and disempowerment of rural women in Ghana", World Development, Vol. 66, pp. 335-345, doi: 10.1016/j.worlddev.2014. 08.027.

Gartaula, H., Patel, K., Johnson, D., Devkota, R., Khadka, K. and Chaudhary, P. (2017), "From food security to food wellbeing: examining food security through the lens of food wellbeing in Nepal's rapidly changing agrarian landscape", Agriculture and Human Values, Vol. 34 No. 3, pp. 573-589, doi: 10.1007/s10460-016-9740-1.

Gonzalez, C.G. (2021), "Racial capitalism, climate justice, and climate displacement”, Onati Socio-Legal Series, Vol. 11 No. 1, pp. 108-147, doi: 10.35295/osls.iisl/0000-0000-0000-1137.

Hallowell, M.R. and Gambatese, J.A. (2009), "Activity-based safety risk quantification for concrete formwork construction”, Journal of Construction Engineering and Management, Vol. 135 No. 10, pp. 990-998, doi: 10.1061/(asce)co.1943-7862.0000071.

Hill, M. and Hupe, P. (2003), "Implementing public policy: governance in theory and in practice", Choice Reviews Online, Vol. 1, doi: 10.5860/choice.40-5441.

Hsieh, H.F. and Shannon, S.E. (2005), “Three approaches to qualitative content analysis”, Qualitative Health Research, Vol. 15 No. 9, pp. 1277-1288, doi: 10.1177/1049732305276687.
Improving women's sustainable development

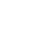


EFCC 3,1
Kansake, B.A., Sakyi-Addo, G.B. and Dumakor-Dupey, N.K. (2021), "Creating a gender-inclusive mining industry: uncovering the challenges of female mining stakeholders", Resources Policy, Elsevier, Vol. 70, p. 101962, doi: 10.1016/j.resourpol.2020.101962.

Khoza, S., Van Niekerk, D. and Nemakonde, L.D. (2019), "Understanding gender dimensions of climate-smart agriculture adoption in disaster-prone smallholder farming communities in Malawi and Zambia", Disaster Prevention and Management: An International Journal, Vol. 28 No. 5, pp. 530-547, doi: 10.1108/DPM-10-2018-0347.

Klege, R.A., Visser, M. and Clarke, R.P. (2021), "Competition and gender in the lab vs field: experiments from off-grid renewable energy entrepreneurs in rural Rwanda", Journal of Behavioral and Experimental Economics, Elsevier, Vol. 91, p. 101662, doi: 10.1016/j.socec.2021. 101662.

Klein, S.J.W. and Whalley, S. (2015), “Author's personal copy author's personal copy criteria decision analysis”, Energy Policy, Vol. 79, pp. 127-149.

Klugman, B. (2009), "Everywhere/nowhere: gender mainstreaming in development agencies", Global Public Health, Vol. 4 No. 5, pp. 502-505, doi: 10.1080/17441690902829828.

Koomson, I. and Danquah, M. (2021), "Financial inclusion and energy poverty: empirical evidence from Ghana", Energy Economics, Elsevier B.V., Vol. 94, p. 105085, doi: 10.1016/j.eneco.2020. 105085 .

Krippendorff, K. (2011), "Agreement and information in the reliability of coding", Communication Methods and Measures, Vol. 5 No. 2, pp. 93-112, doi: 10.1080/19312458.2011.568376.

Kusch-Brandt (2019), "Urban renewable energy on the upswing: a spotlight on renewable energy in cities in REN21's 'renewables 2019 global status report”, Resources, Vol. 8 No. 3, doi: 10.3390/ resources8030139.

Kwame Ameade, E.P. and Majeed, S.F. (2015), "Improving girl child education and menstrual hygiene through free sanitary pad provision to secondary school girls-opinion of female university students in Ghana", Journal of Health Education Research and Development, Vol. 03, p. 143, doi: 10.4172/2380-5439.1000143.

Lambrecht, I.B. (2016), "As a husband I will love, lead, and provide gendered access to land in Ghana”, World Development, Elsevier, Vol. 88, pp. 188-200, doi: 10.1016/j.worlddev.2016.07.018.

Langer, A., Meleis, A., Knaul, F.M., Atun, R., Aran, M., Arreola-Ornelas, H., Bhutta, Z.A., Binagwaho, A., Bonita, R., Caglia, J.M. and Claeson, M. (2015), "Women and Health: the key for sustainable development”, The Lancet, Vol. 386, pp. 1165-1210, doi: 10.1016/S0140-6736(15)60497-4.

Lovelock, C.E. and Reef, R. (2020), "Variable impacts of climate change on blue carbon”, One Earth, Vol. 3 No. 2, pp. 195-211, doi: 10.1016/j.oneear.2020.07.010.

Mahajan, K. (2019), "Back to the plough: women managers and farm productivity in India”, World Development, Vol. 124, p. 104633, doi: 10.1016/j.worlddev.2019.104633.

Martey, E., Etwire, P.M., Atinga, D. and Yevu, M. (2021), "Household energy choice for cooking among the time and consumption poor in Ghana”, Energy, Elsevier, Vol. 226, p. 120408, doi: 10.1016/j. energy.2021.120408.

McKay, F.H., John, P., Sims, A., Kaur, G. and Kaushal, J. (2020), "Documenting the food insecurity experiences and nutritional status of women in India: study protocol", International Journal of Environmental Research and Public Health, Vol. 17 No. 11, p. 3769, doi: 10.3390/ijerph17113769.

Ministry of Energy (2010), "National energy policy: Republic of Ghana”, available at: http://www. petrocom.gov.gh/assets/national_energy_policy.pdf.

Mubaya, C.P., Mafongoya, P.L. and Obert, J. (2017), "Contextualizing gender in climate change adaptation in semi-arid Zimbabwe international journal of climate change strategies and article information", International Journal of Climate Change Strategies and Management, Vol. 9 No. 4, pp. 488-500.

Musango, J.K., Smit, S., Ceschin, F., Ambole, A., Batinge, B., Anditi, C., Petrulaityte, A. and Mukama, M. (2020), "Mainstreaming gender to achieve security of energy services in poor urban 
environments", Energy Research and Social Science, Elsevier, Vol. 70, p. 101715, doi: 10.1016/j. erss.2020.101715.

OECD (2019), "Sustainable connectivity closing the gender gap in infrastructure", No. 15, pp. 1-24, available at: https://www.oecd-ilibrary.org/docserver/6350ba66-en.pdf?expires $=1599226217$ \&id $=$ id\&accname $=$ guest\&checksum $=4$ B71F2F3E11479B0137C62C436331898.

Ogando, A.C., Roever, S. and Rogan, M. (2017), "Gender and informal livelihoods: coping strategies and perceptions of waste pickers in Sub-Saharan Africa and Latin America", International Journal of Sociology and Social Policy, Vol. 37 Nos 7/8, pp. 435-451, doi: 10.1108/IJSSP-062016-0077.

Opoku, E. and Glazebrook, T. (2018), "Gender, agriculture, and climate policy in Ghana", Environmental Ethics, Vol. 40 No. 4, pp. 371-387, doi: 10.5840/enviroethics201840435.

Owusu-Manu, D.G., Adjei, T.K., Sackey, D.M., Edwards, D.J. and Hosseini, R.M. (2020), "Mainstreaming sustainable development goals in Ghana's energy sector within the framework of public-private partnerships: challenges, opportunities and strategies", Journal of Engineering, Design and Technology, Vol. 18 No. 6, pp. 605-524, doi: 10.1108/JEDT-062020-0255.

Pareek, A., Dhankher, O.P. and Foyer, C.H. (2020), "Mitigating the impact of climate change on plant productivity and ecosystem sustainability", Journal of Experimental Botany, Vol. 71 No. 2, doi: 10.1093/jxb/erz518.

Pariyar, A. and Kulathuramaiyer, N. (2019), "Community engagement to gender differentiated impacts of climate change in social media", International Journal of Innovative Technology and Exploring Engineering, Vol. 8 No. 8, pp. 1-2.

Patnaik, S. and Jha, S. (2020), "Caste, class and gender in determining access to energy: a critical review of LPG adoption in India”, Energy Research and Social Science, Elsevier, Vol. 67, p. 101530, doi: 10.1016/j.erss.2020.101530.

Phan, L.T., Jou, S.C. and Lin, J.H. (2019), "Gender inequality and adaptive capacity: the role of social capital on the impacts of climate change in Vietnam", Sustainability, Vol. 11 No. 5, p. 1257, doi: $10.3390 /$ su11051257.

REN21 (2019), REN21. 2019. Renewables 2019 Global Status Report (Paris: REN21 Secretariat), REN21.2019, available at: https://www.ren21.net/wp-content/uploads/2019/05/gsr_2019_full_ report_en.pdf.

Republic of Ghana (2020), "Integrating gender considerations into Ghana's national adaptation plan process", available at: https://napglobalnetwork.org/resource/integrating-genderconsiderations-into-ghanas-nap/.

Rosenthal, J., Quinn, A., Grieshop, A.P., Pillarisetti, A. and Glass, R.I. (2018), “Clean cooking and the SDGs: integrated analytical approaches to guide energy interventions for health and environment goals", Energy for Sustainable Development., Elsevier, Vol. 42, pp. 152-159, doi: 10.1016/j.esd.2017.11.003.

Sandelowski, M. and Leeman, J. (2012), "Writing useable qualitative health research findings", Qualitative Health Research, Vol. 22 No. 12, pp. 1404-1413, doi: 10.1177/1049732312450368.

Scholten, C. and Witmer, H. (2017), "The opaque gendered lens - barriers to recruitment and career development", Gender in Management, Vol. 32 No. 1, pp. 47-65, doi: 10.1108/GM-09-2015-0082.

Sen, G. and Mukherjee, A. (2014), "No empowerment without rights, no rights without politics: genderequality, MDGs and the post-2015 development agenda", Journal of Human Development and Capabilities, Vol. 15 Nos 2-3, doi: 10.1080/19452829.2014.884057.

Senadza, B. (2012), "Education inequality in Ghana: gender and spatial dimensions", Journal of Economic Studies, Vol. 39 No. 6, pp. 724-739, doi: 10.1108/01443581211274647.

Shaaban, M., Scheffran, J., Böhner, J. and Elsobki, M.S. (2018), "Sustainability assessment of electricity generation technologies in Egypt using multi-criteria decision analysis", Energies, Vol. 11 No. 5, pp. 284-297, doi: 10.3390/en11051117.

Improving women's sustainable development 
EFCC 3,1

Simpson, S.N.Y. and Buabeng, D.T. (2013), "Performance contract and performance of public enterprises: a study of the implementation processes", Journal of Public Administration and Governance, Vol. 3 No. 2, pp. 10-21, doi: 10.5296/jpag.v3i2.3792.

Smith, L. (2013), “Working hard with gender: gendered labour for women in male dominated occupations of manual trades and information technology (IT)", Equality, Diversity and Inclusion, Vol. 32 No. 6, pp. 592-603, doi: 10.1108/EDI-12-2012-0116.

Soratto, J., Pires, D.E.P.de and Friese, S. (2020), "Thematic content analysis using ATLAS.ti software: potentialities for researchs in health", Revista brasileira de enfermagem, Vol. 73 No. 3, p. 73, doi: 10.1590/0034-7167-2019-0250.

Tavenner, K., et al. (2019), "Intensifying inequality? Gendered trends in commercializing and diversifying smallholder farming systems in East Africa", Frontiers in Sustainable Food Systems, Vol. 3, p. 10, doi: 10.3389/fsufs.2019.00010.

Tayal, D. (2019), "Gender inequality, reproductive rights and food insecurity in Sub-Saharan Africa - a panel data study", International Journal of Development Issues, Vol. 18 No. 2, pp. 191-208, doi: 10.1108/IJDI-10-2018-0165.

The Beijing Declaration on Research Data (2020), Chemistry International. doi: 10.1515/ci-2020-0313.

Tongco, M.D.C. (2007), "Purposive sampling as a tool for informant selection", Ethnobotany Research and Applications, Vol. 5, doi: 10.17348/era.5.0.147-158.

Tourigny, L., Han, J. and Baba, V.V. (2017), "Does gender matter?: a study of trust and its outcomes in the manufacturing sector in mainland China”, Gender in Management, Vol. 32 No. 8, pp. 554-577, doi: 10.1108/GM-05-2016-0106.

UN (2012), "The future we want: outcome document of the united nations conference on sustainable development", in Rio+20 United Nations Conference on Sustainable Development, available at: https://sustainabledevelopment.un.org/content/documents/733FutureWeWant.pdf.

Vaismoradi, M., Jones, J., Turunen, H. and Snelgrove, S. (2016), “Theme development in qualitative content analysis and thematic analysis", Journal of Nursing Education and Practice, Vol. 6 No. 5, pp. 1-11, doi: 10.5430/jnep.v6n5p100.

Van Meter, D.S. and Van Horn, C.E. (1975), "The policy implementation process: a conceptual framework", Administration and Society, Vol. 6 No. 4, pp. 445-488, doi: 10.1177/ 009539977500600404.

Wang, S.J. and Zhou, L.Y. (2019), "Integrated impacts of climate change on glacier tourism", Advances in Climate Change Research, Vol. 10 No. 2, pp. 71-79, doi: 10.1016/j.accre.2019.06.006.

Whyte, K. (2020), "Too late for indigenous climate justice: ecological and relational tipping points", Wiley Interdisciplinary Reviews: Climate Change, Vol. 11 No. 1, p. 603, doi: 10.1002/wcc.603.

World Commission on Environment and Development (2017), "Brundtland report - our common future, our common future”, available at: https://academic.oup.com/sw/article-abstract/58/4/369/ 2962399.

\section{Corresponding author}

David Mensah Sackey can be contacted at: davidsackey.co.uk@gmail.com

For instructions on how to order reprints of this article, please visit our website:

www.emeraldgrouppublishing.com/licensing/reprints.htm

Or contact us for further details: permissions@emeraldinsight.com 